\title{
Optimization of Cow's Milk Processing into Milk Soap Bar on Small-Medium-Micro Enterprises (UMKM)
}

\author{
Ari Diana Susanti ${ }^{1, \mathrm{a},}$, Sulistyo Saputro ${ }^{2}$, Wusana Agung Wibowo ${ }^{1}$ \\ 1 Department of Chemical Engineering, Universitas Sebelas Maret, Jl. Ir. Sutami No. 36 A, Surakarta, \\ Central Java, 57126 \\ 2 Department of Chemistry, Universitas Sebelas Maret, Jl. Ir. Sutami No. 36 A, Surakarta, Central Java, \\ 57126 \\ E-mail: a,*aridiana@staff.uns.ac.id (Corresponding author)
}

\begin{abstract}
The quality and quantity of cow's milk produced were determined by the genetic, food, age, milking processing, and the treatment of cattle. The storability of fresh cow's milk tends to be short. Therefore, it is necessary to find ways to extend the life time of fresh cow's milk, one of which is by processing fresh cow's milk into other products, such as milk soap bar. The purpose of this study was to determine the appropriate method of milk soap bar production in home industries capacity and to formulate composition of vegetable oils and fresh cow's milk. The milk soap bar obtained then was analyzed in several laboratory tests such as acidity test $(\mathrm{pH})$, moisture content, free alkaline content, and foam stability. Based on the research, it is turned out that the appropriate method of milk soap bar production was the cold process. The optimum formula is olive oil (11\%), coconut oil $(22 \%)$, palm oil (22\%), fresh cow's milk (33\%), and $\mathrm{NaOH}$ pellets ( $12 \%$ - equivalent to $9.2 \mathrm{~N}$ ). The free alkaline content will decrease according the curing time. Simpler economic evaluation obtained that the production cost of milk was Rp.6,711.22/package of 80 grams of milk soap bar. Milk soap bar is sold for Rp. 7,000.00 will provide $87.96 \%$ after-tax of ROI, 11.7 - month of POT, and $65.31 \%$ of BEP.
\end{abstract}

Keywords: cow's milk, milk soap bar, cold processing, free alkaline.

EQUILIBRIUM Volume 2 No.2 July 2018

Online at http:/ / equilibrium.ft.uns.ac.id 


\section{Introduction}

Milk is a liquid obtained from the process of milking livestock such as cattle, goats and buffaloes. According to the Community Empowerment and Village Governance Agency (Badan Pemberdayaan Masyarakat dan Pemerintahan Desa - BPMPD) [1], the factors those influence the quality of milk for dairy cows are type of cattle, food types, cattle age, and milking process. The quality of fresh cow milk is also determined by the method and duration of storage. The shelf life of fresh cow's milk tends to be short. Processing of fresh cow's milk into other food products will extend the storage time, such as into milk powder, UHT milk, cheese, yogurt, ice cream, and butter. Another alternative process that can be done is to use fresh cow's milk, especially low-quality as raw material for milk soap bar production.

According to the National Standardization Agency (Standar Nasional Indonesia - SNI), soap is a cleanser substances made by reacting between alkaline with fatty acids derived from vegetable oils or animal fats which are generally added with fragrances or antiseptics and used to cleanse the human body [2]. The process of soap production is known as the saponification process, triglycerides will be breakdown by reacting with bases such as sodium hydroxide $(\mathrm{NaOH})$. Glycerin is the side product of the saponification process [3]. Fatty acids are saturated or unsaturated long-chain mono carboxylates in different chain lengths but no cyclic or branched [4]. Animal fatty acids those are potential as raw material in making of beauty bath soap are fatty acids from milk, such as cow's milk and goat's milk. Chemically, milk is a fat emulsion in water containing sugar, mineral salts, and proteins in the form of colloidal suspension [5]. Milk fat contains triglycerides (major components), diglycerides, mono glycerides, fatty acids, sterols, carotenoids (yellow color of fat), and vitamins $(\mathrm{A}, \mathrm{D}, \mathrm{E}$, and $\mathrm{K})[\mathrm{G}]$.

Milk soap is made from fresh milk and natural ingredients which are reacted with lye ( $\mathrm{NaOH}$ solution) as an alkaline agent. Lye in the manufacture of milk soap usually does not leave a residue because it has reacted into soap and glycerin [7]. The method of home mades's soap bar is mostly done by cold process and hot process [8]. The differences of hot process and cold process is heating process involvement. Heating in hot process will shorten the duration of soap bar's curing time.

In this study, a series of experiments were conducted to determine appropriate milk saponification method, to select the kind of vegetable oils, and to formulate the optimum composition of vegetable oils used in saponification process. In addition, in this study, a simple economic evaluation was also carried out on the calculation of specific production costs, estimated selling prices, Return on Investment (ROI) as annual profit divided by total investment, Pay Out Time (POT) as total investment divided by annual profit and depreciation, and Break Even Point (BEP). The results of the economic evaluation were used to forecast the economic potential of milk soap bar production from fresh cow's milk.

\section{Methodology}

The materials used in making of milk soap bar are fresh cow's milk, $\mathrm{NaOH}$, olive oil, coconut oil, and palm oil. While chemicalia used in the product testing are distilled water, $96 \%$ alcohol, $\mathrm{HCl}, \mathrm{KOH}, \mathrm{H}_{2} \mathrm{SO}_{4}, \mathrm{BaCl}_{2}$, and phenolphtalein indicators.

\section{Results and Discussions}

\subsection{The Appropriate Method of Milk Soap Bar Production}

In this study, the home-made milk soaps bar production from fresh cow's milk were carried out through cold process and hot process. Milk soap bar made by cold process is white and in a homogeneous form. While milk solid bar produced through hot process is brownish and separate into two layers. Therefore, the appropriate method used in the production of milk soap bar is cold process.

\subsection{Qualitative and Quantitative Characterization.}

Qualitative characterization of vegetable oils is intended to determine the effect of the type of vegetable oil used as the correctional raw material. The considerations is based on the physical appearance of milk soap bar produced and the results were shown in Table 1. 
Table 1. Physical properties of milk soap bar made with ingredients of various vegetable oils

\begin{tabular}{cccc}
\hline Vegetable Oils & Colour & Texture & Foamability \\
\hline Olive oil & Yellowish & Soft & Low \\
Coconut oil & White & A little hard & High \\
Palm oil & Brownish & Very hard & Low \\
Olive oil + Coconut oil + Palm oil & White & Hard & High \\
\hline
\end{tabular}

The used of olive oil as ingredient will produced soap with soft texture on skin but has low foamability, coconut oil make soap produced has slightly hard texture but high foamability, and palm oil will produce soap with properties of very dense and low foamability. Therefore it is necessary to optimize the formulation of soap making using ingredients mixed of olive oil, coconut oil and palm oil.

Quantitative characterization is intended to determine the saponification value which is the amount of bases that must be added to the vegetable oil/ fat in the perfect saponification process. The results are presented in Table 2 .

Table 2. Test results of sapofication value test of various vegetable oils and fat

\begin{tabular}{lcc}
\hline Materials & Saponification Value Test & Saponification Value Literature \\
\hline Olive oil & 190,09 & $184-196^{\mathrm{a}}$ \\
Coconut oil & 258,16 & $250-264^{\mathrm{b}}$ \\
Palm oil & 199,21 & $196-206^{\mathrm{b}}$ \\
Cow's fresh milk & 58,28 & - \\
\hline a [9] & & \\
b $[10]$ & &
\end{tabular}

The sequence of saponification values from the largest to the less is coconut oil, palm oil, and olive oil. The greater the saponification value indicates the more bases used for perfect saponification. The main components of fatty acids in coconut oil are lauric acid (C11), while in palm oil are palmitic acid (C15), and in olive oil are oleic acid (C17-1 double bond), and linoleic acid (C17-2 double bond ) The saponification of fresh cow's milk is relatively small because the fat content in fresh cow's milk is only $3.3 \%$ [11].

The desired soap bar is fresh cow's milk-based soap bar, so cow's milk in the soap is the major component in order to obtain benefits of cow's milk on skin health and beautification. Therefore, the formulation of the raw material for making milk soap bar is carried out with variations in the amount of fresh cow's milk. The formula for making milk soap bar and the results of observations are presented in Table 3 .

Table 3. Formulations of milk soap bar and the results of the observations in the process production

\begin{tabular}{|c|c|c|c|c|c|c|c|c|}
\hline \multirow[b]{2}{*}{$\begin{array}{l}\text { Code of } \\
\text { Formula }\end{array}$} & \multicolumn{5}{|c|}{ Components (\%weight) } & \multirow[b]{2}{*}{$\begin{array}{l}\text { Mixing } \\
\text { Time, min }\end{array}$} & \multirow[b]{2}{*}{ Molding } & \multirow[b]{2}{*}{ Stiffness } \\
\hline & $\begin{array}{l}\text { Cow's } \\
\text { Milk }\end{array}$ & $\begin{array}{c}\text { Olive } \\
\text { Oil }\end{array}$ & $\begin{array}{c}\text { Coconut } \\
\text { Oil }\end{array}$ & $\begin{array}{c}\text { Palm } \\
\text { Oil }\end{array}$ & $\mathrm{NaOH}$ & & & \\
\hline P1 & 14 & 28 & 28 & 14 & 15 & 3 & Hard & +++ \\
\hline P2 & 25 & 25 & 25 & 12 & 14 & 5 & Slightly hard & ++ \\
\hline P3 & 33 & 22 & 22 & 11 & 12 & 8 & Easy & + \\
\hline
\end{tabular}

The higher cow's milk content in the raw materials the longer mixing time need, but the less dense of milk soap bar produced and the more easy of molding and the less of soap bar stiffness. So, the formulation of $\mathrm{P} 3$ will be used in the next investigation. According to SNI [12], the water content in soap bar is a maximum of $15 \%$. Milk soap bar produced from the formulation has met SNI quality criteria $(0,77 \%)$. Water content in milk soap bar comes from fresh cow's milk.

\subsection{Curing Time Investigation.}

The $\mathrm{pH}$ of milk soap bar shows that milk soap bar is an alkaline substance, and the higher the $\mathrm{pH}$ value also describes the presence of the residual base. So to be able to use, milk soap bar must be saved in time (curing 
The effect of curing time was observed on the P3 product and is presented in Figure 1. The free alkali content is seen to decrease with increasing time. After 26 days the free alkaline level was dropped by $59.7 \%$. Based on the equation of the line obtained, the free alkaline content will disappear after about 82 days.

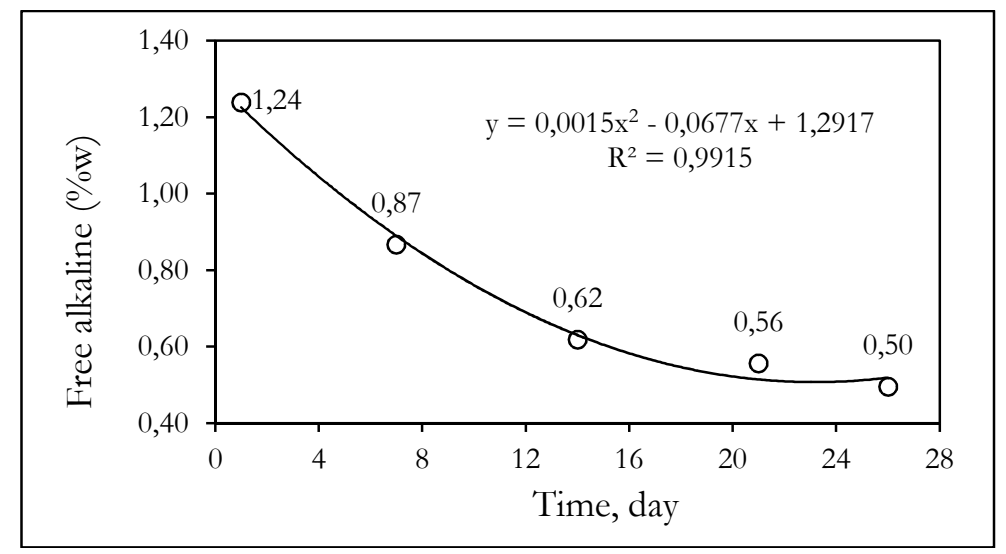

Fig. 1. The effect of curing time on the value of free alkaline content of P3 milk soap bar formulated

\subsection{Simple Economic Evaluation.}

A simple economic evaluation shows that the production costs for producing 80 grams of soap with 2000 soaps / month is Rp. 6,711.22. Soaps are sold for Rp. 7,000.00 which will provide $87.96 \%$ of ROI after tax, 11.7 months of POT, and $65.31 \%$ of BEP.

\section{Clonclusions}

From the laboratory works, it clearly shown that the cold process is the appropriate method for making milk soap bar. Usage of olive oil as ingredient will affect to properties of soap those are soft on skin and feels moist, coconut oil produces soap with a lot of foam, and palm oil produces solid / hard soap. The optimum formula for the manufacture of solid milk soap is olive oil (11\%), coconut oil $(22 \%)$, palm oil (22\%), fresh cow milk $(33 \%)$, and pellet $\mathrm{NaOH}(12 \%$ - equivalent to $9.2 \mathrm{~N})$. The free alkali content in the product from the formulation will decrease with curing time. Product formulations are relatively acceptable to prospective customers.

\section{Acknowledgement}

The authors is grateful to Universitas Sebelas Maret for the financial support through funding scheme Program Kuliah Kerja Nyata (PKKN) - PNBP UNS 2018 contract number 544/UN27.21/PM/2018.

\section{References}

[1] Badan Pemberdayaan Masyarakat dan Pemerintahan Desa (BPMPD). 2017. http://bpmpd.ntbprov.go.id/index.php/2017/04/04/faktor-peningkat-kualitas-susu-sapi/. Accessed on May 26th 2018.

[2] Badan Standarisasi Nasional. Standar Nasional Indonesia (SNI). Sabun Mandi Padat. 1994. SNI.

[3] Barel, A. O., Paye, M., dan Maibach, H.I. Handbook of Cosmetic Science and Technology. 3rd Ed. New York: Informal Healthcare USA, Inc. 2009.

[4] Winarno, F. G. Kimia Pangan dan Gizi. Jakarta: PT Gramedia. 1997.

[5] Rahman, A. S., Fardian, Rahayu, W. P., Suliantari, Nurwitiri, C.C. Teknologi Fermentasi Susu. Bogor: Direktorat Jendral Pendidikan Tinggi. 1992.

[6] Bylund G. Dairy Processing Handbook, 1st ed. Lund (SE): Tetra Pal Processing Systems AB.

[7] Husnawati. Penerapan Pengendalian Mutu pada Susu UHT di PT Prima Japfa Jaya. Bogor Institut Pertanian Bogor. 2002.

[8] Dana. 2016. Cara Membuat Sabun Mandi Sederhana. https://banaransoap.com/cara-membuat-sabunmandi-sendiri/. 1995. Accessed on May 27th 2018.

[9] Peraturan Kepala Badan Pengawas Obat dan Makanan Republik Indonesia Nomor 21 Tahun 2016 tentang Kategori Pangan 
[10] Ketaren, S. Pengantar Teknologi Minyak dan Lemak Pangan. Jakarta: UI Press. 1986.

[11] Maheswari, R.R.A., dan Ronny, R. N. Perbandingan Kandungan Nutrisi ASI, Susu Sapi, dan Susu Kambing. Bogor: Institut Pertanian Bogor. 2008.

[12] Badan Standarisasi Nasional. Standar Nasional Indonesia (SNI). Susu Segar. 2011. SNI.O. I. Nwaukwu IA, "Generation of Biogas from Cow Dung," J. Bioremediation Biodegrad., vol. 5, no. 2, pp. 2-4, 2014. 